\title{
"Global deoffshorization and its impact on the national and regional economies of eastern european countries"
}

\begin{tabular}{|c|c|}
\hline AUTHORS & $\begin{array}{l}\text { Svitlana Khalatur (D https://orcid.org/0000-0001-8331-3341 } \\
\mathbb{R} \text { https://publons.com/researcher/T-7645-2019 } \\
\text { Gediminas Radzevicius (D https://orcid.org/0000-0001-8617-5482 } \\
\text { Liudmyla Velychko (D https://orcid.org/0000-0002-8255-8774 } \\
\mathbb{R} \text { https://publons.com/researcher/2015009/velichko-lyudmila/ } \\
\text { Valeriia Fesenko (D https://orcid.org/0000-0002-0317-0895 } \\
\mathbb{R} \text { http://www.researcherid.com/rid/J-5404-2018 } \\
\text { Lesia Kriuchko (D) https://orcid.org/0000-0002-7490-3523 }\end{array}$ \\
\hline ARTICLE INFO & $\begin{array}{l}\text { Svitlana Khalatur, Gediminas Radzevicius, Liudmyla Velychko, Valeriia Fesenko } \\
\text { and Lesia Kriuchko (2019). Global deoffshorization and its impact on the national } \\
\text { and regional economies of eastern european countries. Problems and } \\
\text { Perspectives in Management, 17(3), 293-305. doi:10.21511/ppm.17(3).2019.24 }\end{array}$ \\
\hline DOI & http://dx.doi.org/10.21511/ppm.17(3).2019.24 \\
\hline RELEASED ON & Monday, 02 September 2019 \\
\hline RECEIVED ON & Thursday, 27 December 2018 \\
\hline ACCEPTED ON & Tuesday, 30 July 2019 \\
\hline LICENSE & $\begin{array}{l}(0) \text { EY } \\
\text { This work is licensed under a Creative Commons Attribution } 4.0 \text { International } \\
\text { License }\end{array}$ \\
\hline JOURNAL & "Problems and Perspectives in Management" \\
\hline ISSN PRINT & $1727-7051$ \\
\hline ISSN ONLINE & $1810-5467$ \\
\hline PUBLISHER & LLC "Consulting Publishing Company "Business Perspectives" \\
\hline FOUNDER & LLC "Consulting Publishing Company "Business Perspectives" \\
\hline
\end{tabular}

NUMBER OF REFERENCES

35
NUMBER OF FIGURES

1
ニニニ

NUMBER OF TABLES

6

(C) The author(s) 2022. This publication is an open access article. 


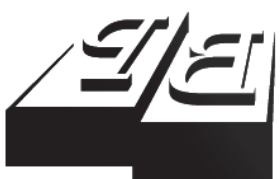

BUSINESS PERSPECTIVES

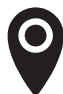

LLC "CPC "Business Perspectives" Hryhorii Skovoroda lane, 10, Sumy, 40022, Ukraine

www.businessperspectives.org

Received on: $27^{\text {th }}$ of December, 2018 Accepted on: $30^{\text {th }}$ of July, 2019

(C) Svitlana M. Khalatur, Gediminas Radzevicius, Liudmyla A. Velychko, Valeriia V. Fesenko, Lesia S.

Kriuchko, 2019

Svitlana M. Khalatur, Doctor of Economics, Associate Professor of Finance, Banking and Insurance Department, Dnipro State Agrarian and Economic University, Ukraine.

Gediminas Radzevicius, Doctor, Associate Professor of Economics, Director, European Regional Policy Institute, Lithuania.

Liudmyla A. Velychko, Ph.D. (Public Administration), Senior Lecturer, Department of Economics, Entrepreneurship and Management of Enterprises, Oles Honchar Dnipro National University, Ukraine.

Valeriia V. Fesenko, Doctor of Economics, Associate Professor, Department of Accounting, Audit, Analysis and Taxation, University of Customs and Finance, Ukraine.

Lesia S. Kriuchko, Ph.D., Associate Professor, Marketing Department, Dnipro State Agrarian and Economic University, Ukraine.

\section{(ㄷ)(ㄱ)}

This is an Open Access article, distributed under the terms of the Creative Commons Attribution 4.0 International license, which permits unrestricted re-use, distribution, and reproduction in any medium, provided the original work is properly cited.

Svitlana M. Khalatur (Ukraine), Gediminas Radzevicius (Lithuania), Liudmyla A. Velychko (Ukraine), Valeriia V. Fesenko (Ukraine), Lesia S. Kriuchko (Ukraine)

\title{
GLOBAL DEOFFSHORIZATION AND ITS IMPACT ON THE NATIONAL AND REGIONAL ECONOMIES OF EASTERN EUROPEAN COUNTRIES
}

\begin{abstract}
In recent years, deoffshorization is a trend and dozens of countries have already started an open fight against offshore accounts. Ukraine is moving to complete deoffshorization in accordance with the new rules for exchanging information on financial accounts and BEPS rules. The purpose of the study was to search for optimal solutions for further improvements in the field of deoffshorization of the national and regional economy of the Eastern European contries, in particular Ukraine. The following methods were used to solve the problems in the work: induction and deduction (in the study of offshore types, the definition of interconnection and interdependence between them), abstract-logical (in generalizing the theoretical foundations of economic deoffshorization ), econometric-statistical (in assessing the state and dynamics of export-import operations of Ukraine with offshore jurisdictions), statistical analysis.

On the basis of theoretical and empirical conclusions, the main consequences, which are the result of the study of global deoffshorization in conditions of financial control and its influence on the national and regional economy of Ukraine, are presented. The article provides a correlation analysis of the dependence of the export index to the UK from Ukraine with export, import and balance of offshore countries. A study was conducted on the presence or absence of a relationship between the volume of balance, exports and imports from Ukraine to the United Kingdom with the macroeconomic indicators of the national economy of Ukraine.
\end{abstract}

\section{Keywords}

JEL Classification D51, E26, O19

offshores, midshores, onshores, export, import, GDP, taxes, capital

\section{INTRODUCTION}

Offshores are a purely negative phenomenon that the public perceives to be very critical, or a habitual phenomenon that opens up new opportunities for doing business. Today, the whole business is trying to avoid offshore, as the world community has taken an active deoffshorization course. In addition, the urgent problem is the attraction of foreign investments into the economy of the country and regions. Investment processes directly affect the dynamics of socio-economic development of regions and the state as a whole. Foreign investment is a significant part of the country's investment potential. World experience demonstrates the dependence of foreign direct investment with well-developed infrastructure, a favorable business environment (low costs for starting a business, low level of corruption, and the work efficiency of local authorities). The existing benefits stimulate investors to invest and create business in the region. 
Given the growing uncertainty within the global economy and the increasing turbulence of the international capital market, global risks for Ukraine are quite significant. The use of the benefits of financial globalization while minimizing its risks requires the application of specific regulation of capital inflow-outflow. Globalization in the modern world has greatly influenced the intensification of the competitive struggle between the world countries for investments, technologies, and jobs.

\section{LITERATURE REVIEW}

Many aspects of taxation, management and deoffshorization of the economy were considered by many scholars. So, Zizlavsky's (2016) work is based on knowledge in the field of innovation management and managerial control. Issues of management and evaluation of the effectiveness of the innovation process are considered. Attention is focused on the effective spending of resources throughout the innovation process.

Kedziora, Kraslawski, and Kärri (2016) understand the business process of offshore as the transfer of individual business tasks to a country with different rules than the country's own rules. Today, offshoring has become a global strategy for most companies around the world.

Ruiu (2018) argues that fatalism can affect professional choices and preservation of the decision of economic agents. It is necessary to understand the economic behavior of demand for assets from entrepreneurs, since entrepreneurs have a large volume of financial assets. Šramko (2015) is considering the idea of taxation of financial transactions. The scientist writes that in addition to increasing incomes, the taxation of financial transactions is intended to prevent financial transactions that do not increase the efficiency of the market and as a consequence restrain the excess volatility of financial markets.

Zhang (2017) proposed a model developed as part of a dynamic general equilibrium with heterogeneous households and progressive income taxation. Public finances are substantially supported by tax revenues. Zhang (2017) describes a model with a dynamic interaction between economic growth, the accumulation of wealth and progressive taxation of profits at the international level.

D. C. Vu, Lee, and H. L. Vu (2016) argue that the greatest concern among governments in many countries is to optimize the implementation of segregated financial elements into a single system for economic development of countries. Kalinina (2016) notes that, for example, income tax is one of the most important taxes in Russia, which, together with the value added tax and corporate profit tax, provide the largest revenues to the state budget.

Ameur and Tkiouat (2016) write that the behavior of fraudulent taxpayers negatively affects the resources available to finance the country's main government spending. Fraud scams create unfair competition and cause damage to other taxpayers. Bobrova (2016) argues that when entering into the interaction with respect to taxation, subjects of tax relations often move from the zone of the hidden conflict to the open.

Sinenko and Mayburov (2017) in their studies consider special economic zones that are widely used globally as a tax tool for further development and attracting foreign investment. Tax exemptions of special economic zones have a great influence on investment decisions of enterprises. Balseven and Tugcu (2017) write that equality in income distribution has become an important topic in the study of modern macroeconomics. In the process of globalization, countries have lost the flexibility to use fiscal policy. Valipour, Homayoun, and Piran (2017) rightly point out that financing is one of the most important measures and supports strategic investment of enterprises. Financial indicators are related to financial statements and tax expenses of enterprises.

Ebi and Ayodele (2017) write that governments in many countries need revenue to maintain an adequate level of public investment and social services, while taxes are the main source of increased incomes in both developed and developing countries. Huda, Nugraheni, and Kamarudin (2017) are studying transfer pricing, which comes from an attempt to control 
the other party through its owner. Martina (2017) writes that the tax structure is the main form of government revenues and the main instrument for implementing state fiscal policy. Mahmood, Saeed, Ali, Hasti, and Elyasi (2018) consider technology firms that play an important role in job creation, national competitiveness and innovation, and the search for funding in each country. Harahap, Sinaga, Manurung, and Maulana (2018) write that the tax is about $70 \%$ of the country's state budget, which makes it extremely important for the functioning of the governance and development of each state.

Hong, Hsu, and Li (2018) argue that the financial crisis in 2008 has significantly increased country debt and reduced their fiscal space, causing difficulties in introducing national insurance in most countries. Hong, Tsai, Lee, and Dang (2018) write that after the financial crisis, Taiwan's economic growth has slowed down, increasing its budget deficit, and tax reform has become a solution. Suprihanti, Harianto, Sinaga, and Kustiari (2018) look at one of the industries that plays an important role in the Indonesian economy - this is the tobacco sector. The future of the epidemic of tobacco-related illnesses lie in low- and middle-income countries, where tobacco sales are rising as a result of rising incomes and trade liberalization.

Jihene and Moez (2019) write that taxes are a major concern for businesses as it affects competitiveness. In this context, enterprises are not satisfied with passive tax administration. Avoiding taxes is considered to be the main problem that threatens the national economy. Awounang and Foning (2014) note that the most macroeconomic variables show high volatility in developing countries. This uncertainty environment affects the investment. Zirgulis (2014) considers corporate income taxation, which generates high incomes for governments, especially for industrialized countries. Thus, the issue of tax competition is extremely important for the governments of the countries. A better understanding of tax competition will provide managers with the best tools for tax policy formation.

Consequently, the study of global deoffshorization and its impact on the national and regional economy of eastern European contries, in particular Ukraine, is relevant.

\section{AIMS}

The study purpose is to search the optimal solutions for further improvements in the field of deoffshorization of the national and regional economy of eastern European contries, in particular in Ukraine.

\section{METHOD AND METHODOLOGY}

The theoretical and methodological basis of the research is the dialectical method of cognition, scientific development and publication of domestic and foreign scientists on taxation, management and deoffshorization of the economy. The following methods were used to solve the problems in the work: induction and deduction (in the study of offshore types, the definition of interconnection and interdependence between them), abstract-logical (in generalizing the theoretical foundations of economic deoffshorization), econometric-statistical (in assessing the state and dynamics of export-import operations of Ukraine with offshore jurisdictions), statistical analysis (in determining the impact, presence or absence of connection between the volume of balances, exports and imports from Ukraine to the UK with macroeconomic indicators of the national economy of Ukraine).

The research structure is based on data from the State Statistics Committee of Ukraine, the National Bank of Ukraine, the World Bank. The study was conducted on the basis of data for 2002-2017. The national economy of Ukraine is the main unit of research interest. In the concept of global deoffshorization decisions in this research, a systematic approach is considered, which studies the situation in the context of external and internal circumstances. The analysis is used to obtain new information and its interpretation. The need to strengthen the field of knowledge about deoffshorization of the national economy was identified by means of empirical research, serves to present the authors' opinion about global deoffshorization in Ukraine under financial control for offshore operations. 


\subsection{Directions for further improvement in the deoffshorization field of national and regional economies}

Deoffshorization in recent years is already a certain trend, which is also mandatory, and dozens of countries have already started an open fight against offshore accounts. Ukraine is moving towards a total deoffshorization under the new rules for information exchange on financial accounts (CRS) and BEPS rules. There is also the MLI Agreement, which has now joined 68 countries. It provides for the introduction of amendments to more than 1,200 double taxation conventions, which will, in particular, increase preferential rates for repatriation of income.

Offshores have already gained such popularity that even certain kinds of them appeared. The most popular are classical offshore, which are typical of Panama, Belize and others. Companies registered in such an offshore are used to protect assets and reduce the tax burden for businesses. Classical offshore companies are not authorized to conduct any activity in the country of their registration. A characteristic feature of classical offshore is that companies registered in such offshore companies pay only a fixed tax. These companies are exempted from tax reporting.

For a more detailed disclosure of the research topic, it will be analyzed how the volumes of exports and imports in the national economy of Ukraine have changed during 2002-2017 (Figure 1). In 2017, as compared to 2002, Ukraine's exports, imports, and balance are growing, respectively, by USD 25307641.2 thousand, (by 2.4 times), by USD 32630339.4 thousand (almost by 3 times); by USD 5362177,6 thousand (almost by 6.5 times).

Export under-invoicing is the most common method of global illegal leakage of capital. It accounts for $52 \%$ of all global capital withdrawal transactions. In the second place, it is an import over-invoicing $-31.5 \%$.

In Table 1, the comparative dynamics of exportimport operations of Eastern European countries is analyzed.

According to Table 1, among the studied countries of Eastern Europe, export-import operations tend to increase in 2017 compared to 2009, which indicates the active foreign economic activity of these countries.

Exporting from Ukraine to the offshore or importing to Ukraine can reflect both real supplies of goods and be an element of chain of the trade and financial transactions. Trade and financial transactions are aimed at minimizing taxation and concealing information about actual currency earnings. Let's consider the foreign economic activity of Ukraine with the countries - classical offshores. The following countries are selected for research: Panama, Seychelles, Belize, the Bahamas (Table 2).

Source: Authors' calculations according to the data from the State Statistics Committee of Ukraine, the National Bank of Ukraine, the World Bank.

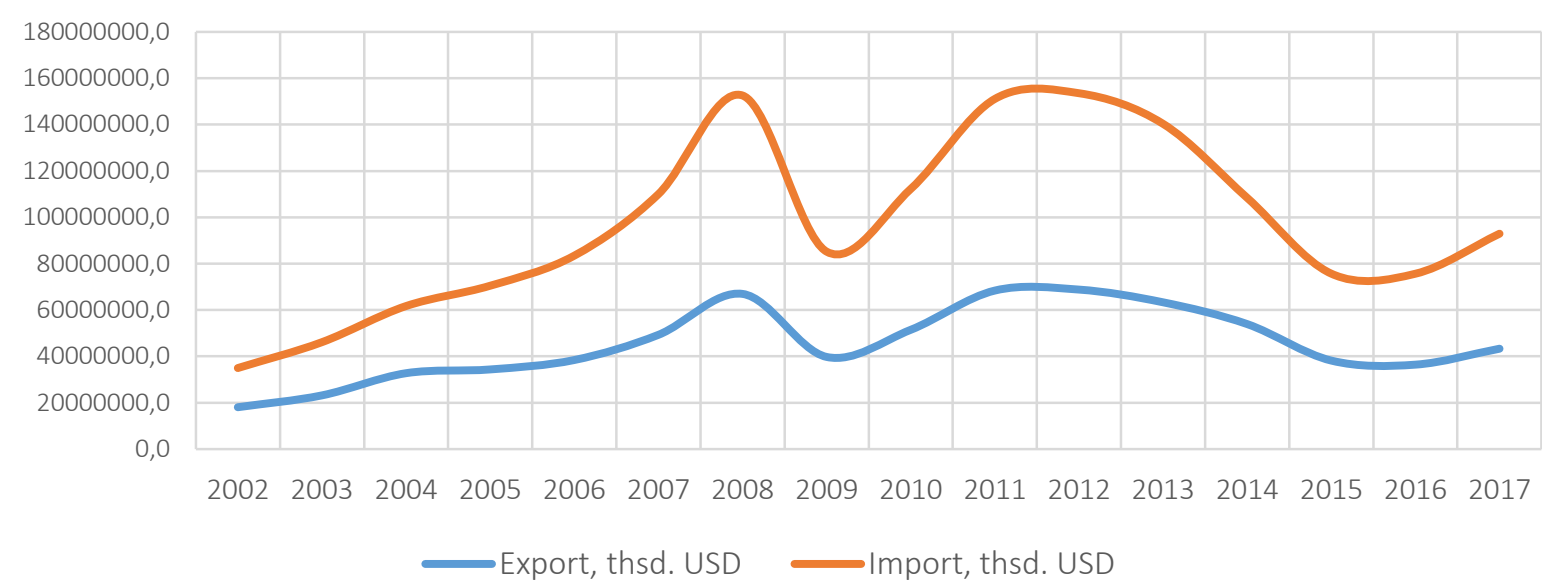

Figure 1. Dynamics of volumes of export and import in the national economy of Ukraine during 2002-2017 
Table 1. Comparative dynamics of export-import operations of Eastern European countries

\begin{tabular}{|c|c|c|c|c|c|c|c|}
\hline \multirow{2}{*}{ Indicator } & \multicolumn{6}{|c|}{ Years } & \multirow{2}{*}{ Ratio, \% } \\
\hline & 2009 & 2013 & 2014 & 2015 & 2016 & 2017 & \\
\hline \multicolumn{8}{|c|}{ Belarus } \\
\hline Exports of goods and services (\% of GDP) & 48.88 & 58.33 & 54.94 & 58.01 & 62.51 & 67.04 & 137.16 \\
\hline Exports of goods and services (USD mln) & 24310,30 & 44046,10 & 43302,90 & 32797,80 & 29926,90 & 36529,50 & 150.26 \\
\hline Imports of goods and services (\% of GDP) & 59.76 & 61.48 & 55.71 & 57.90 & 62.70 & 67.06 & 112.22 \\
\hline Imports of goods and services (USD mln) & 29918,30 & 46387,00 & 43791,80 & 32697,10 & 29958,90 & 36446,60 & 121.82 \\
\hline \multicolumn{8}{|c|}{ Latvia } \\
\hline Exports of goods and services (\% of GDP) & 42.60 & 60.30 & 60.74 & 60.42 & 59.98 & 61.09 & 143.40 \\
\hline Exports of goods and services (USD mln) & 11400,77 & 18219,51 & 19025,96 & 16289,16 & 16553,32 & 18374,79 & 161.17 \\
\hline Imports of goods and services (\% of GDP) & 44.22 & 63.85 & 62.19 & 60.93 & 58.82 & 61.00 & 137.94 \\
\hline Imports of goods and services (USD mln) & 11591,73 & 19342,48 & 19482,33 & 16428,03 & 16305,27 & 18783,17 & 162.03 \\
\hline \multicolumn{8}{|c|}{ Lithuania } \\
\hline Exports of goods and services (\% of GDP) & 51.94 & 84.06 & 81.10 & 75.82 & 74.10 & 80.90 & 155.77 \\
\hline Exports of goods and services (USD mln) & 19539,52 & 39046,07 & 39259,62 & 31393,65 & 31817,89 & 38623,79 & 197.67 \\
\hline Imports of goods and services (\% of GDP) & 53.62 & 82.81 & 79.03 & 76.30 & 72.82 & 78.11 & 145.67 \\
\hline Imports of goods and services (USD mln) & 20160,45 & 38470,36 & 38341,42 & 31667,26 & 31299,23 & 37272,91 & 184.88 \\
\hline \multicolumn{8}{|c|}{ Moldova } \\
\hline Exports of goods and services (\% of GDP) & 36.87 & 43.34 & 41.53 & 42.80 & 43.46 & - & - \\
\hline Exports of goods and services (USD mln) & 1708,87 & 3040,67 & 2958,71 & 2488,42 & 2608,05 & 3101,60 & 181.50 \\
\hline Imports of goods and services (\% of GDP) & 73.49 & 80.60 & 78.53 & 73.86 & 70.94 & - & - \\
\hline Imports of goods and services (USD mln) & 370,74 & 6027,0 & 5872,27 & 4479,88 & 4466,84 & 5353,71 & 144.40 \\
\hline
\end{tabular}

Analyzing Table 2, it can be concluded that the Then, the trend went down, and since 2017, trade largest volume of export-import operations in with classical offshores has risen again. It should Ukraine among investigated offshore is with also be emphasized that exports to the classical Panama. During 2015-2016, there is no overall offshore almost in all the studied years several foreign economic activity of Ukraine with the times exceeded the import value. In the first place, Bahamas and Seychelles. Most actively, Ukraine this happens because of the phenomenon of re-exexported goods to the classical offshore, and al- port, when the product is sold to the company in so imported them from there during 2012-2013. the offshore, and already it sells it to other coun-

Table 2. Dynamics of Ukrainian international trade indicators with classical offshores during 20022017, USD thsd.

Source: Data from the State Statistics Committee of Ukraine, World Bank.

\begin{tabular}{|c|c|c|c|c|c|c|c|c|}
\hline Classic offshores & 2002 & 2011 & 2012 & 2013 & 2014 & 2015 & 2016 & 2017 \\
\hline \multicolumn{9}{|c|}{ Panama } \\
\hline Export & 13076,0 & 22499,8 & 29825,7 & 28945,3 & 31531 & 9908,4 & 13904 & 28125 \\
\hline Imports & 477,2 & 11190,0 & 19741,6 & 16548,4 & 1713,2 & 11807 & 2414,3 & 1280,9 \\
\hline Balance & 12598,85 & 11309,8 & 10084,1 & 12396,8 & 29818 & $-1899,2$ & 11490 & 26845 \\
\hline \multicolumn{9}{|c|}{ Seychelles } \\
\hline Export & 1,99 & 1536,7 & 3288,5 & 1507,1 & 289,5 & - & - & 3748,9 \\
\hline Imports & 148,5 & 85 & 442,9 & 74 & 384,6 & - & - & 526,4 \\
\hline Balance & $-146,51$ & 1451,7 & 2845,6 & 1433 & $-95,1$ & - & - & 3222,5 \\
\hline \multicolumn{9}{|c|}{ Belize } \\
\hline Export & 1883,81 & 7524,5 & 225175,4 & 174718,5 & 360,3 & 3666,9 & 930,2 & 10517 \\
\hline Imports & 507,06 & 480 & 1052,7 & 5457,1 & 5629,1 & 28,4 & 710,2 & 865,8 \\
\hline Balance & 1376,75 & 7044,5 & 224122,7 & 169261,4 & $-5268,8$ & 3638,4 & 220 & 9651,3 \\
\hline \multicolumn{9}{|c|}{ The Bahamas } \\
\hline Export & 1833,47 & 22,9 & 5096,5 & 73,8 & - & - & - & 13224 \\
\hline Imports & 1492,96 & 1647,8 & 554,3 & 231,5 & - & - & - & - \\
\hline Balance & 340,51 & $-1625,0$ & 4542,2 & $-157,7$ & - & - & - & 13224,2 \\
\hline
\end{tabular}


tries. There are plenty of ways to withdraw money from offshore zones, and their list is constantly replenished with new schemes. However, international trade, ie import and export, is one of the most profitable and widely used ways in which cash flows into offshore zones.

In addition to offshores, there are also midshores and onshores. The midshores are one offshore type that includes jurisdictions that occupy an intermediate position between classical offshore areas and high tax "prestigious" jurisdictions. Midshores are jurisdictions that adhere to all international transparency standards and actively implement them in their national legislation (for example, they implement an open register of company owners), known for their stable financial and banking sector, as well as low tax rates. However, in comparison with classical offshore zones, midshores have a bunch of advantages. They have the same authority and level of trust, as well as high tax jurisdictions. In addition, midshores, unlike many classic offshores, are part of the OECD white list, for example, Britain, Ireland, Cyprus, and Hong Kong. They are more attractive in tax terms compared to high tax jurisdictions.

But there are cases when in deoffshorization business conditions companies are better to choose other jurisdictions - onshores. Onshore is the jurisdiction of highly developed, non-taxed countries, taxes are usually charged at rates of $20 \%$ or more, they have very high reporting and business transparency requirements, but at the same time a very developed and strong financial sector. These onshores include the Netherlands, Germany, Switzerland, Austria, Liechtenstein and other countries. Onshore is a completely different level of doing business. Currently, onshore is practically not popular, as well as midshore, because of their complexity and high cost of service. But for companies that are more important than a name, a prestige, as well as an additional bonus in the form of the benefits of avoiding double taxation, the offshore jurisdictions will work best. It often happens that the partners themselves and suppliers put harsh boundaries and requirements for the companies in the jurisdiction in which the company should be registered and where the bank account should be opened for successful cooperation. In this case, companies will definitely choose onshore.

Since the volume of international trade of Ukraine with midshores during 2002-2017 is the greatest with Great Britain, for a more detailed disclosure of the research topic, a correlation analysis of the dependence of the Ukraine export indicator to

Table 3. Dynamics of Ukrainian international trade indicators with midshores during 2002-2017, USD thsd.

Source: Data from the State Statistics Committee of Ukraine, World Bank.

\begin{tabular}{|c|c|c|c|c|c|c|c|c|}
\hline Midshores & 2002 & 2011 & 2012 & 2013 & 2014 & 2015 & 2016 & 2017 \\
\hline \multicolumn{9}{|c|}{ United Kingdom } \\
\hline Export & 537043,6 & 485739 & 551421 & 547214 & 589211 & 367897 & 317792 & 480025 \\
\hline Import & 263018,3 & 1128551 & 1149469 & 1132419 & 692044 & 570127 & 709262 & 798949 \\
\hline Balance & 274025,2 & -642812 & -598048 & -585204 & -102833 & -202230 & -391470 & -318924 \\
\hline \multicolumn{9}{|c|}{ Ireland } \\
\hline Export & 2269,16 & 14660,5 & 75979,7 & 120847 & 69479,4 & 59182,6 & 45483,9 & 55298,4 \\
\hline Import & 25443,5 & 168316,5 & 152631 & 191487 & 134006 & 75396,4 & 84712,5 & 113890 \\
\hline Balance & $-23174,34$ & -153656 & -76651 & -70640 & -64527 & -16213 & -39228 & -58591 \\
\hline \multicolumn{9}{|c|}{ Cyprus } \\
\hline Export & 200957,2 & 174415,8 & 168047 & 161554 & 283724 & 61526,1 & 53481,4 & 79637,6 \\
\hline Import & 17000,28 & 143933 & 79550,9 & 70320,8 & 50298,8 & 16922,9 & 22081,6 & 20527,1 \\
\hline Balance & 183956,92 & 30482,8 & 88496,4 & 91234,1 & 233426 & 44603,3 & 31399,9 & 59110,5 \\
\hline \multicolumn{9}{|c|}{ Hong Kong } \\
\hline Export & 34855,24 & 30768 & 16831,6 & 24491,9 & 25864,3 & 15439,5 & 49013,4 & 54074,8 \\
\hline Import & 4209,75 & 28495 & 20004,6 & 29910 & 17186,4 & 12246 & 17629,9 & 29120,1 \\
\hline Balance & 30645,49 & 2272,9 & $-3173,0$ & $-5418,1$ & 8677,9 & 3193,5 & 31383,4 & 24954,7 \\
\hline \multicolumn{9}{|c|}{ New Zealand } \\
\hline Export & 2037,32 & 3526 & 4265,4 & 5210,6 & 2075,5 & 1891,9 & 2555,8 & 2039,9 \\
\hline Import & 901,07 & 22575,5 & 38257,6 & 41884,9 & 42635,7 & 9966,7 & 10873,8 & 13130,6 \\
\hline Balance & 1136,25 & $-19049,5$ & -33992 & -36674 & -40560 & $-8074,8$ & $-8318,1$ & -11090 \\
\hline
\end{tabular}


Table 4. Dynamics of Ukrainian international trade indicators with onshores during 2002-2017, USD thsd.

UK with export, import, and balance of investi- lowing indicators: imports from Ireland, imports gated offshore countries was conducted. In Table from New Zealand, imports from the Netherlands, 5 , the coefficients of correlation are more than $0.5 ;$ and imports from Germany. Interesting results namely there is a direct or inverse relationship.

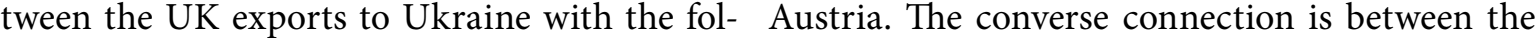

Table 5. Correlation of the dependence of the export indicator to the UK from Ukraine with the export, import, and balance indicators of the investigated offshore countries

Source: Authors' calculations according to the data from the State Statistics Committee of Ukraine, the National Bank of Ukraine, the World Bank.

\begin{tabular}{c|cc}
\hline Coefficient of correlation & Indicator & Country \\
\hline 0.605235 & Imports, thsd. USD & Ireland \\
\hline-0.59423 & Balance, thsd. USD & Hong Kong \\
\hline 0.698714 & Imports, thsd. USD & New Zealand \\
\hline 0.592647 & Imports, thsd. USD & Netherlands \\
\hline 0.550323 & Imports, thsd. USD & Germany \\
\hline-0.96022 & Balance, thsd. USD & Germany \\
\hline-0.68704 & Balance, thsd. USD & Switzerland \\
0.700995 & Exports, thsd. USD & Austria \\
\hline 0.519244 & Imports, thsd. USD & Austria \\
0.853335 & Balance, thsd. USD & Austria \\
\hline
\end{tabular}


indicators of exports to the United Kingdom of Ukraine with the following indicators: the balance of foreign trade of Ukraine with Hong Kong, the balance of foreign trade of Ukraine with Germany and the balance of foreign trade of Ukraine with Switzerland. There is no correlation between the indicators of international trade of Ukraine with classical offshore countries.

Next, a study was conducted on the presence or absence of a relationship between the volume of balance, exports and imports in USD thsd. from Ukraine to Great Britain with the following indicators: GDP growth (annual \%), GDP per capita growth (annual \%), GDP (current USD), GDP per capita (current US\$), General government final consumption expenditure (\% of GDP), GNI (current USD), GNI per capita growth (annual \%), GNI per capita, Atlas method (current USD), Gross capital formation (\% of GDP), Gross capital formation (annual \% growth), Gross capital formation (current USD), Gross domestic savings (\% of GDP), Gross fixed capital formation (\% of GDP), Gross national expenditure (\% of GDP), Gross value added at factor cost (current USD), Household final consumption expenditure (annual \% growth), Household final consumption expenditure (current USD), IMF charges (INT, current USD), Industry, value added (\% of GDP), Inflation, GDP deflator (annual \%), Profit tax (\% of commercial profits), Tax payments (number), Tax revenue (\% of GDP), Taxes on exports (\% of tax revenue), Taxes on exports (current LCU), Taxes on goods and services (\% of revenue), Taxes on goods and services (\% value added of industry and services), Taxes on goods and services (current LCU), Taxes on income, profits and capital gains (\% of revenue), Taxes on income, profits and capital gains (\% of total taxes), Taxes on income, profits and capital gains (current LCU), Taxes on international trade (\% of revenue), Taxes on international trade (current LCU), Total tax rate (\% of commercial profits). Table 6 summarizes the correlation coefficients of more than 0.5. That confirms the presence of direct or converse connection between the indicators.

Analyzing Table 6, there is a relationship between the volumes of exports from Ukraine to the UK with the following indicators: GDP, GDP per capita, GNI, GNI per capita, Household final consumption expenditure, Taxes on international trade feedbacks. Direct correlation between import volumes from Ukraine to the UK with the following indicators: GDP, GDP per capita, GNI, GNI per capita, Gross capital formation, Gross do-

Table 6. Coefficients of the correlation of the indicators of balance, export and import from Ukraine to the United Kingdom with the researched indicators

Source: Authors' calculations according to the data from the State Statistics Committee of Ukraine, the National Bank of Ukraine, the World Bank.

\begin{tabular}{|c|c|c|c|c|c|}
\hline Export (dependence) & $\begin{array}{l}\text { Correlation } \\
\text { coefficient }\end{array}$ & Import (dependence) & $\begin{array}{l}\text { Correlation } \\
\text { coefficient }\end{array}$ & Balance (dependence) & $\begin{array}{l}\text { Correlation } \\
\text { coefficient }\end{array}$ \\
\hline GDP (current USD) & 0.565977 & GDP (current USD) & 0.883277 & GDP (current USD) & -0.62815 \\
\hline $\begin{array}{l}\text { GDP per capita (current } \\
\text { USD) }\end{array}$ & 0.575602 & $\begin{array}{l}\text { GDP per capita (current } \\
\text { USD) }\end{array}$ & 0.875452 & $\begin{array}{l}\text { GDP per capita (current } \\
\text { USD) }\end{array}$ & -0.59213 \\
\hline GNI (current USD) & 0.571276 & GNI (current USD) & 0.886443 & GNI (current USD) & -0.62603 \\
\hline $\begin{array}{l}\text { GNI per capita, Atlas } \\
\text { method (current USD) }\end{array}$ & 0.545738 & $\begin{array}{l}\text { GNI per capita, Atlas } \\
\text { method (current USD) }\end{array}$ & 0.736636 & $\begin{array}{l}\text { GNI per capita, Atlas } \\
\text { method (current USD) }\end{array}$ & -0.50408 \\
\hline $\begin{array}{l}\text { Gross value added at factor } \\
\text { cost (current USD) }\end{array}$ & 0.565833 & $\begin{array}{l}\text { Gross capital formation } \\
\text { (current USD) }\end{array}$ & 0.903805 & $\begin{array}{l}\text { Gross capital formation } \\
\text { (annual \% growth) }\end{array}$ & -0.59889 \\
\hline $\begin{array}{l}\text { Household final } \\
\text { consumption expenditure } \\
\text { (current USD) }\end{array}$ & 0.507433 & $\begin{array}{l}\text { Gross national expenditure } \\
\text { (\% of GDP) }\end{array}$ & 0.714221 & $\begin{array}{l}\text { Gross capital formation } \\
\text { (current USD) }\end{array}$ & -0.69832 \\
\hline \multirow{4}{*}{$\begin{array}{l}\text { Taxes on international trade } \\
\text { (\% of revenue) }\end{array}$} & \multirow{4}{*}{-0.52032} & $\begin{array}{l}\text { Gross value added at factor } \\
\text { cost (current USD) }\end{array}$ & 0.882378 & $\begin{array}{l}\text { Gross value added at } \\
\text { factor cost (current USD) }\end{array}$ & -0.66146 \\
\hline & & \multirow{3}{*}{$\begin{array}{l}\text { Household final } \\
\text { consumption expenditure } \\
\text { (current USD) }\end{array}$} & \multirow{3}{*}{0.761985} & $\begin{array}{l}\text { Household final } \\
\text { consumption expenditure } \\
\text { (current USD) }\end{array}$ & -0.55542 \\
\hline & & & & $\begin{array}{l}\text { Taxes on exports (current } \\
L C U)\end{array}$ & -0.85058 \\
\hline & & & & $\begin{array}{l}\text { Taxes on income, profits } \\
\text { and capital gains (\% of } \\
\text { revenue) }\end{array}$ & -0.68668 \\
\hline
\end{tabular}


mestic expenditure, Household final consumption expenditures. There is a reverse significant relationship between the volume of the balance from Ukraine to the UK with the following indicators: GDP, GDP per capita, GNI, GNI per capita, Gross capital formation, Gross value added at factor cost, Household final consumption expenditure, Taxes on exports, Taxes on income, profit and capital gains. There are no significant relationships with other studied parameters.

In recent years, the world community is concerned about the activities of offshore companies. Every year new approaches are developed to combat offshore. Therefore, it is fair to note that the world has begun a global process of deoffshorization of the world economy. In a broad sense, deoffshorization is the counteraction to the erosion of the tax base and the elimination of tax-free profits (anti-BPPS). BEPS is defined precisely as the dilution of the tax base and the withdrawal of profit from taxation. In the narrow sense, deoffshorization is the identification of profits, deduced in low tax and offshore jurisdictions, and taxation of such profits.

If to distinguish these features in a separate concept, deoffshorization is a complex of measures at the state level in its various spheres, in particular in the legal, legislative and informational, to reduce or exclude the possibilities of erosion of the tax base or the elimination of tax-free profits. The purpose of deoffshorization is to include in the general corporate tax base companies to stop the tax base's dilution.

\section{DISCUSSION}

Kjediora, Kraslawski, and Kärri (2016) argue that there are many factors contributing to the dynamic growth of the offshore business industry, for example, reducing trade barriers and transport costs, as well as technological changes. Kedziora, Kraslawski, and Kärri (2016) also wrote that the multinational financial management is difficult, and most offshore business organizations are multinational or global. The results of Šramko (2015) assess changes in French and Italian policy of taxation of financial transactions. Zhang (2017) studied economic growth, economic structural changes and the accumulation of wealth in a het- erogeneous household economy. Kalinina (2016) argues that it is possible to construct a progressive tax scale, taking into account the likelihood of tax evasion, or to ensure the equality of profitability of taxes.

Ameur and Tkiouat (2016) noted that there is a difference between methods and tools for tax fraud and tax audit. Tax administrations should be interested in understanding the manifestations of tax fraud and its causes. Bobrova (2016) systematized the problems and causes of the antagonism of subjects of tax legal relations to create an effective and optimal model of interaction between tax entities.

Summarizing the experience of carrying out a comprehensive assessment of the impact of special economic zones on their native territories, Sinenko and Mayburov (2017) identified key components of the analysis: fiscal, social and economic indicators of regional development. Tax breaks provided by special economic zones are criticized on the grounds that they destroy the tax base and reduce budget revenues without significant regional gain. The results obtained by Sinenko and Mayburov (2017) testify that the creation of special economic zones has yielded significant positive results for the development of regions.

The study by Balseven and Tugcu (2017) examines the impact of fiscal policies on income distribution by comparison between groups of developing and developed countries. Huda, Nugraheni, and Kamarudin (2017) note that transfer pricing is carried out in the form of minimizing tax expenditures without tax regulation (tax avoidance) and conducting transactions to minimize tax liabilities without complying with regulation ( $\operatorname{tax}$ evasion). From a study conducted by Martina (2017), it is clear that for the three types of tax structure the highest percentage of income from indirect taxes - from VAT, and in direct - from the income tax. Harahap, Sinaga, Manurung, and Maulana (2018) say that if the government plans to increase tax revenues, it should ensure the stability of macroeconomic conditions and establish an optimal tax rate, as well as continue to increase revenues from tax the sector. Hong, Tsai, Lee, and Dang (2018) confirm that an increase in the tax rate will lead to higher prices. Once inflation is 
triggered, it will increase consumption and production costs. According to Zirgulis (2014), an acknowledgment of the existence of tax competition between countries makes an important contribution to studying the relationship between productivity shocks and changes in tax rates. Despite the relatively small relationship between tax rates and productivity, Zirgulis (2014) has confirmed that shocks from foreign productivity have a negative impact on housing tax rates.

This study considers the influence of global deoffshorization on foreign economic activity of enterprises of the national economy of Ukraine. It is true that favorable tax conditions are attracting international business. The enterprises have an opportunity to optimize the taxation of their profits. Of course, the introduction of offshore zones in certain countries only enriched the economies of these countries, creating an uneven flow of capital between countries. Enriching the economies of certain countries due to attractive tax conditions creates problems for the world economy. The presence of offshore zones, on the one hand, stimulates the foreign economic activity, but on the other hand, does not create fair conditions for business.

Today, almost all the countries of the world hold the deoffshorization course. International rules of the game are changing, they need to be adapted. At present, the use of offshore structures without their proper declaration becomes very risky for enterprises.

Global deoffshorization requires international business to perform its foreign economic activity on an equal footing. This will ensure fair and open rules of the game, in which each company will develop its foreign economic activity. The disappearance of offshore will contribute to a uniform distribution of taxes and investments between countries. It will be beneficial both for the global economy as a whole and for the economy of each state separately.
Under conditions of global deoffshorization, capital will move between countries on identical terms. This will ensure the flow of capital without favoring countries with more attractive taxation conditions. From now on, world business will choose other conditions when choosing a jurisdiction to conduct its foreign economic activity. Weighing all the advantages and disadvantages of global deoffshorization, it will have a positive impact on the foreign economic activity. Establishing the same and fair economic conditions will help attract investment in the country, regardless of whether they have preferential tax treatment or not. Today, the world community is moving towards ensuring the flow of capital evenly into the world economy, which will create real prerequisites for the development of foreign economic relations. The world business will have more opportunities to choose the jurisdiction of its foreign trade activities.

Over the past few years, Ukraine has actually been struggling to tackle withdrawal of capital offshore, despite the fact that the high level of shadow economy in Ukraine greatly complicates state control over capital movements. The disadvantages in the system of state regulation of foreign economic activity create a favorable ground for the dissemination of various schemes for the withdrawal of capital from Ukraine, which are used for tax evasion and laundering of proceeds from crime. Consequently, the implementation of BEPS measures, in the context of rules and the mandatory exchange of tax information, will stimulate Ukrainian business to turn off offshore profits.

At the regional level, registering or cooperating with offshore companies can demonstrate how an enterprise is doing business. Especially it is necessary to consider in detail the situation, if such operations in offshore jurisdictions are dozens or hundreds. It is better to think about the transparency of the enterprise, which cooperates massively with offshore.

\section{CONCLUSION}

The largest volume of export-import operations among investigated offshores in Ukraine is with Panama. During 2015-2016, there is no overall foreign economic activity of Ukraine with the Bahamas and Seychelles. Ukraine shipped the largest amount of goods for export to classical offshores, and re- 
ceived imports from classical offshores for 2012-2013. During 2014-2016, there is a decline in Ukraine's export and import operations with classical offshore companies. Since 2017, the volume of exports and imports with classical offshores has risen again. The value of exports from Ukraine to the classical offshores during the investigated period in several times exceeded the value of imports. This situation is due to the fact that goods are sold to an offshore company, and then it sells this product to enterprises in other countries. There is a large number of ways to withdraw capital in the offshore, and there are constantly new schemes. However, international trade, i.e. import and export, is one of the most profitable and widely used ways in which cash flows into offshore zones.

Since the volume of international trade of Ukraine with midshores during 2002-2017 is the greatest with the United Kingdom, for a more detailed disclosure of the research, a correlation analysis of the dependence of the UK export indicator on exports to countries of origin, imports and balance of offshore countries has been conducted. The analysis showed a direct relationship between the UK exports to Ukraine with the following indicators: imports from Ireland, imports from New Zealand, imports from the Netherlands, and imports from Germany. Interesting results are the direct relationship between the magnitude of exports to the UK with Ukraine and the indicators of international trade between Ukraine and Austria. There is indirect correlation between the indicators of exports to Great Britain from Ukraine with the following indicators: the balance of foreign trade of Ukraine with Hong Kong, the balance foreign trade of Ukraine with Germany and the balance foreign trade of Ukraine with Switzerland. There is no correlation between the indicators of international trade of Ukraine with the countries of classical offshore.

A study was also conducted on the presence or absence of a relationship between the volume of balances, exports and imports from Ukraine to the United Kingdom with the macroeconomic indicators of the national economy. The relationship between exports from Ukraine to the UK was as follows: GDP, GDP per capita, GNI, GNI per capita, Household final consumption expenditure, Taxes on international trade (feedback). Direct correlation is between import volumes from Ukraine to the UK with the following indicators: GDP, GDP per capita, GNI, GNI per capita, Gross capital formation, Gross domestic expenditure, Household final consumption expenditures. There is a reverse significant relationship between the volume of international trade balance of Ukraine with the United Kingdom with the following indicators: GDP, GDP per capita, GNI, GNI per capita, Gross capital formation, Gross value added at factor cost, Household final consumption expenditure, Taxes on exports, Taxes on income, profit and capital gains. There are no significant relationships with other studied parameters.

The research results can be used to enhance managerial attention and identify problems can help prevent errors in the economy's deoffshorization. Managers can compare and find results, and thus enrich knowledge collections to make informed decisions. In addition, this study continued to search for optimal solutions for further improvements in the field of deoffshorization on the national and regional economy of Ukraine. In further research, the correlation between the magnitudes of exports to classical offshores, onshores and midshores will be studied. There is direct correlation with the decrease of exports to classical offshore; exports to onshore and midshares are increasing.

\section{REFERENCES}

1. Aggarwal, S., \& Klapper, L. (2013) Designing Government Policies to Expand Financial Inclusion: Evidence from Around the World. Retrieved from http://www.isb. edu/faculty/shilpa_aggarwal/files/ shilpa-aggarwal-leora-klapper.pdf
2. Ameur, F., \& Tkiouat, M. (2016). A Contribution of Expected Utility Theory in Taxpayers' Behavior Modeling. International Journal of Economics and Financial Issues, 6(3), 1217-1224. Retrieved from http://www.econjournals.com/ index.php/ijefi/article/download $/ 2411 /$ pdf

3. Awounang, A. C., \& Foning, M. N. (2014). Macroeconomic Volatility and Physical Capital Accumulation in Sub-Saharan Africa. International Journal of Economic 
Sciences, III(2), 112-129. Retrieved from https://www.iises.net/macroeconomic-volatility-and-physicalcapital-accumulation-i.html

4. Balseven, H., \& Tugcu, C. T. (2017). Analyzing the Effects of Fiscal Policy on Income Distribution: A Comparison between Developed and Developing Countries. International Journal of Economics and Financial Issues, 7(2), 377-383. Retrieved from https://www.econjournals.com/ index.php/ijefi/article/view/4235

5. Bobrova (2016). Positional Antagonism of Subjects of Tax Relation. International Journal of Economics and Financial Issues, 6(S2) 260-267. Retrieved from https://www.researchgate.net/ publication/304891258_Positional_antagonism_of_subjects_ of_tax_relation

6. Ebi, B. O., \& Ayodele, O. (2017). Tax Reforms and Tax Yield in Nigeria. International Journal of Economics and Financial Issues, 7(3), 768-778. Retrieved from https://ideas.repec.org/a/eco/ journ1/2017-03-98.html

7. Harahap, M., Sinaga, B. M., Manurung, A. H., \& Maulana, T. N. A. (2018). Impact of Policies and Macroeconomic Variables on Tax Revenue and Effective Tax Rate of Infrastructure, Utility, and Transportation Sector Companies Listed in Indonesia Stock Exchange. International Journal of Economics and Financial Issues, 8(3), 95-104. Retrieved from https://ideas.repec. org/a/eco/journ1/2018-03-12.html

8. Hong, C.-Y., Hsu, C.-J., \& Li, J.-F. (2018). The Economic Effects of the Tax Reform: Dynamic Input-output Model Approach. International Journal of Economics and Financial Issues, 8(4), 140146. Retrieved from http://www. econjournals.com/index.php/ijefi/ article/view/6585

9. Hong, C.-Y., Tsai, Y.-C., Lee, T.-R., \& Dang, H.-W. (2018). Tax Rate Adjustment and Its Potential Impact on Price: An Application Mathematical Input-Output Price Spillover Model. International Journal of Economics and Financial Issues, 8(5), 21-25. Retrieved from https://ideas.repec.org/a/eco/ journ1/2018-05-4.html

10. Huda, M. K.., Nugraheni, N., \& Kamarudin, K. (2017). The Problem of Transfer Pricing in Indonesia Taxation System. International Journal of Economics and Financial Issues, 7(4), 139143. Retrieved from https://www. econjournals.com/index.php/ijefi/ article/view/4793

11. Jakubowska, A., \& Horváthová, Z. (2016). Economic Growth and Health: a Comparative Study of the EU Countries. Economics and Sociology, 9(3), 158-168. https://doi.org/10.14254/2071789X.2016/9-3/14

12. Jihene, F., \& Moez, D. (2019). The Moderating Effect of Audit Quality on CEO Compensation and Tax Avoidance: Evidence from Tunisian Context. International Journal of Economics and Financial Issues, 9(1), 131-139. https://doi. org/10.32479/ijefi.7355

13. Kalinina, O. (2016). An Innovative Approach to the Formation of a Progressive Taxation Probabilistic Model on Personal Incomes. International Journal of Economics and Financial Issues, 6(3), 9951002. Retrieved from http://www. econjournals.com/index.php/ijefi/ article/view/2100

14. Kedziora, D., Kraslawski, A., \& Kärri, T. (2016), Off shored Service Cost Model as a Key Post-Transition Challenge. Journal of International Studies, 9(3), 229-240. https://doi. org/10.14254/2071-8330.2016/9$3 / 18$

15. Khalatur, S., Pavlova, G., \& Zhylenko, K. (2018). The role of some indicators of financial security in Ukraine in the context of transnationalization and national interests. Investment Management and Financial Innovations, 15(3), 237-248. https://doi.org/10.21511/ imfi.15(3).2018.20

16. Larsen, M. M. (2015). Failing to estimate the costs of offshoring: A study on process performance. International Business Review, 25(1), 307-318. https://doi.org/10.1016/j. ibusrev.2015.05.008
17. Loorbach, D. (2013). Business transition management: exploring a new role for business in sustainability transitions. Journal of Cleaner Production, 45, 20-28. https://doi.org/10.1016/j. jclepro.2012.11.002

18. Mahmood, M., Saeed, S., Ali, B., Hasti, C., \& Elyasi, G. M. (2018). Institutional Barriers to Financing Technology-based Small Firms through Venture Capital Mechanism: A Study to Explore the Incentives for Investment in Iran. International Journal of Economics and Financial Issues, 8(1), 184195. Retrieved from https://www. econjournals.com/index.php/ijefi/ article/view/5821

19. Marquardt, J. (2015). How transition management can inform development aid. Environmental Innovation and Societal Transitions, 14, 182-185. Retrieved from https://papers.ssrn.com/sol3/papers.cfm?abstract_id=2632953

20. Martina, Y. D. (2017). Comparative Analysis of the Tax Structures of Bulgaria, Denmark and France. International Journal of Econom$i c s$ and Financial Issues, 7(5), 25-32. Retrieved from http://www. econjournals.com/index.php/ijefi/ article/view/5220

21. Official site of the National Bank of Ukraine (n.d.). External sector statistics of Ukraine. Retrieved from www.bank.gov.ua

22. Official site of the State Statistics Service of Ukraine (n.d.). Foreign economic activity. Retrieved from www.ukrstat.gov.ua

23. Ruiu, G. (2018). Can Fatalism Explain why Entrepreneurs Tend to Save so Much? Economics and Sociology, 11(1), 293-310. https://doi.org/10.14254/2071789X.2018/11-1/19

24. Sinenko, O., \& Mayburov, I. (2017). Comparative Analysis of the Effectiveness of Special Economic Zones and Their Influence on the Development of Territories. International Journal of Economics and Financial Issues, 7(1), 15-122. Retrieved from https://www. econjournals.com/index.php/ijefi/ article/view/3374 
25. Šramko, F. (2015). The impact of Securities Transaction Tax on market quality: Evidence from France and Italy. International Journal of Economic Sciences, IV(3), 52-93. https://doi. org/10.20472/ES.2015.4.3.004

26. Suprihanti, A., Harianto, H., Sinaga, B. M., \& Kustiari, R. (2018). The Impact of Cigarette Excise Tax Policy on Tobacco Market and Clove Market in Indonesia. International Journal of Economics and Financial Issues, 8(6), 54-60. Retrieved from https://ideas.repec. org/a/eco/journ1/2018-06-8.html

27. Valipour, H., Homayoun, S., \& Piran, F. (2017). Determinants of Corporate Financial Factors on Tax Reporting Strategy. International Journal of Economics and Financial Issues, 7(3), 377-381. Retrieved from https://ideas.repec. org/a/eco/journ1/2017-03-49.html

28. Velychko, O. (2014). Integrated modeling of solutions in the system of distributing logistics of a fruit and vegetable coopera- tive. Business: Theory and Practice, 15(4), 362-370. https://doi. org/10.3846/btp.2014.480

29. Velychko, O., \& Velychko, L. (2017). Logistical modelling of managerial decisions in social and marketing business systems. Journal of International Studies, 10(3), 206-219. Retrieved from http://dx.doi.org/10.14254/20718330.2017/10-3/15

30. Vu, D. C., Lee, K., \& Vu, H. L. (2016). An Empirical Analysis of the Prominent Roles of Taxation in the Synchronicity on Boost of Maritime Industry in Singapore. International Journal of Economics and Financial Issues, 6(1), 118131. Retrieved from http://www. econjournals.com/index.php/ijefi/ article/view/1604

31. World Bank (n.d.). World development indicators. Retrieved from http://www.worldbank.org

32. Zhang, W.-B. (2017). Business Cycles with Progressive Income Taxation. International Journal of Business and Management, V(2),
78-95. https://doi.org/10.20472/ BM.2017.5.2.006

33. Zirgulis, A. (2014). Is International Capital Tax Competition Fueled by the Quest for Increased Productivity? International Journal of Economic Sciences, III(4), 99-116. Retrieved from https://www.iises.net/is-international-capital-tax-competitionfueled-by-the-quest.html

34. Zizlavsky, O. (2016). The Use of Financial and Nonfinancial Measures within Innovation Management Control: Experience and Research. Economics and Sociology, 9(4), 41-65. https://doi.org/10.14254/2071789X.2016/9-4/3

35. Розпорядження Кабінету Міністрів України «Про віднесення держав до переліку офшорних зон» від 23.02.2011 № 143-p. [Rozporiadzhennia Kabinetu Ministriv Ukrainy «Pro vidnesennia derzhav do pereliku ofshornykh zon» vid 23.02.2011 № 143-r.]. Retrieved from https:// zakon.rada.gov.ua/laws/show/1432011-\%D1\%80 